\title{
Evolution of Political Process in Gulf
}

\author{
Trukhin A.S. \\ Belgorod state technological university \\ named after V.G. Shukhov \\ Belgorod, Russia
}

\author{
Lesovik R.V. \\ Belgorod state technological university \\ named after V.G. Shukhov \\ Belgorod, Russia \\ ruslan_lesovik@mail.ru, lesovik.rv@bstu.ru
}

\author{
Allakham Ya. S. \\ Belgorod state technological university named after V.G. Shukhov \\ Belgorod, Russia \\ intecun@yahoo.com
}

\begin{abstract}
This article analyzes the relations in the CCASPG, disclosure issues of integration processes in the region, showing the contradictions with Qatar regarding the association "Muslim Brotherhood." In addition, the authors shed light on the Russian state interests in the Arabic Gulf, as well as demonstrate the position of the GCC member states concerning the role of our country in the Middle East.
\end{abstract}

Keywords: The Arabic Gulf, the change of power in Saudi Arabia, Gulf Union, "Muslim Brotherhood", inter-religious conflict, the interests of Russia.

\section{INTRODUCTION}

Modern political processes are developing in the context of strengthening new centers of economic growth and political influence, strengthening the interdependence of events. The evolution of political processes in the Arabic Gulf zone is of interest, which is the epicenter of the intersection of geopolitical interests of the world's leading countries, including Russia. In this region, instability within states and in relations between them increases. The "Arab awakening", the growing demand for reforms, the escalation of tensions associated with the activities of the IS increases the uncertainty in the future of this region, the likelihood of changing forms of government and organization.

A significant impact on the evolution of political processes in the countries of the Arabic Gulf is: the growth of sociopolitical differentiation of the population, the existence of inter-confessional conflicts, the interference of external forces in internal affairs, the growth of the mobility of individuals, the expansion of political participation of the population in the life of the country, the weakening of the influence on national politics of traditional generic and clan political elites, the expansion of ideological and value pluralism.

Political processes in the Gulf shows that reforming the "traditional" society can lead not only to a "universal", "partial", "catch-up" political modernization, but also to its "identity", "retrogressive", "dead-end" species. Westernization, the linear transfer of Euro-American political standards to the political field of the Arab countries, as a rule, is ineffective. Their full implementation in the political life of the East is hampered by the millennial foundations of the Arab society, the mentality of the local population, clannishness, tight control of monarchies over political processes [1].

As the editor-in-chief of the Kuwaiti newspaper "Arab Times", A. Jaralla, "the imposition of democratic schemes on the peoples of the region and provocative support for Arab" revolutions "undermines the stability of the US moderate Moderates." As a result, this region is increasingly becoming a source of conflicts of a new generation. Among them, the growth of political extremism, the influence of radical Muslim trends of political orientation [2].

The states of the region (KSA, UAE, Kuwait, Qatar, Bahrain, Oman) are united in the organization of the Cooperation Council of the Arab States of the Persian Gulf (CCASPG). Within the framework of this structure, there are a number of ambitious integration projects that seriously stall. The parties cannot agree on the introduction of a single currency of the Gulf, the timing of the launch of the TransArabian railway, the unified energy system of the region, etc., are postponed.

The locomotive of integration processes in the Gulf - Saudi Arabia stands for the creation of the Gulf Union on the basis of CCASPG. The leadership of the KSA believes that the Union of the Persian Gulf countries should become a "single political state entity" operating on a nonfederal basis under the auspices of Riyadh [3].

The Union, according to the Saudi idea, will ensure the development of a unified political and economic line, as well as effective coordination in the field of defense and security. One of the main goals of the union will be the confrontation of the IS, as well as Iran. 
The idea of transformation of the CCASPG to the Union is supported by Bahrain, who realizes that only integration processes with the Kingdom of Saudi Arabia are able to ensure the stability of the Al-Khalifa regime in the face of growing internal and external threats in connection with the ShiiteSunni confrontation.

Representatives of the UAE, Oman, Kuwait, Qatar believe that the union of the six Gulf countries has rather "vague" prospects due to differences in political systems, uneven economic development, low level of trade among themselves, uneven distribution of hydrocarbon resources, and so on.

Let us note that a number of Arab experts are skeptical about the idea of Riyadh. The point is that the CCASPG allows us to closely integrate: in its statutory documents, the idea of a gradual transformation of this structure into a fullfledged union modeled on the EU [4]. Regional analysts in this regard argue that it is necessary to continue systematic work within the framework of the Cooperation Council of the Arab States of the Persian Gulf. Kuwait experts believe that it is not advisable for the emirate to join the Gulf Alliance proposed by the Saudis, as in the current regional situation, it is necessary to preserve the possibility of pursuing its own more flexible foreign policy course, primarily in relations with Iraq and Iran, mainly to ensure its own security.

A number of political experts of the UAE see hegemonic aspirations in the initiatives of Saudi Arabia, as well as inconsistency with the political and clan interests in their countries, socio-economic realities. Against this background, Oman's refusal to participate in the creation of the Union of the Persian Gulf countries in December 2013 was met with understanding by a number of countries in the region. At the same time, the main reason prompting Sultan Oman Qaboos to take this step is the obvious anti-Iranian orientation of the Saudi initiative, the implementation of which will sharpen the confrontation between the members of the planned union and Tehran [5].

The positions of some members of the GCC are different on a number of other issues, which makes their "unity" rather shaky. Thus, the confrontation over political issues, in particular, the attitude towards the association of the "Muslim Brotherhood", which could be mitigated for a while at the end of the GCC Summit in Doha in December 2014, became more acute.

The catastrophe with the Muslim Brotherhood Association. In fact, Riyadh, and from his submission to Abu Dhabi and Manama, for reasons of preserving the appearance of the unity of the Arabian monarchies before the general threats, have so far been contented with the partial adjustment of their foreign policy by the Qatarians.

Therefore, the demands to Doha to stop all contacts with the "Brothers-Muslims" are removed and transformed into "some mutual understanding" on this issue. The Qatari people managed to insist on their arguments that their contacts with the Brothers not only do not contradict the interests of the CCASPG, but on the contrary, they make it possible to clarify the intentions of the Muslim Brotherhood influential in the Sunni world, to timely bring their position in controversial issues to prevent the emergence of insoluble conflicts between political aspirations of the Brothers and the interests of the Middle Eastern monarchies. The leadership of the KSA, Bahrain, the least willingly, the UAE adopted such a position on the condition that the Qatar people act as a guarantor of the non-directional policy of the Brothers in the region against the regimes of the CCASPG countries [6].

The Saudis expect that in the coming year the chairmanship in the CCASPG of Doha will not be limited to formal compliance with the statutory requirements of the bloc for coordinating foreign policy and non-interference in the internal affairs of its neighbors, but will fully participate in the implementation of integration initiatives.

At the same time, Riyadh clearly understands that it is not a question of the complete denial of the Doha from the ambitions of an independent regional political force and the decrease in the degree of influence on it from Washington. For Qatar, this is rather a natural tactical compromise, the strength of which has yet to be experienced, since no one feels unqualified trust in the Muslim Brotherhood and Qatar.

The most rigid position with respect to the Doha is preserved by the UAE. They are not satisfied with the "halfhearted", essentially cosmetic steps of the Qatar people in adjusting their approaches to ABM. As a condition for the normalization of relations with Doha, Abu Dhabi puts an obvious and real cessation by the Qataris of the financing of $\mathrm{ABM}$ and the expulsion of all its ideologists from Qatar. In this dispute Qatarians show perseverance and point to the lack of Abu Dhabi's right to dictate its will to the sovereign emirate. Moreover, the Qatarians put forward counter demands, one of which is the expulsion from the UAE of M. Dakhlian, the Palestinian adviser to Prince Mohammed bin Zayed, who formulates, in the opinion of Doha, the tough approaches of the UAE leadership to ABM and Qatar. In addition, between the ruling elites of Qatar and the UAE there is a hidden competition for the status of a regional financial center, and the main "trump card" of the Doha, as opposed to Dubai's banking authority, is the ABM link, ready to entrust the banks controlled by the Qatarians with the storage of their monetary assets estimated at more than 100 billion US dollars. In fact, the differences between Doha and Abu Dhabi are currently insurmountable without serious concessions from one of the parties.

It was only under the personal influence and even pressure of the previous Saudi King Abdullah that Muhammad bin Zayed succeeded in obtaining Abu Dhabi's consent to go publicly to settle all disputes in the CCASPG to preserve image positions, which is vitally important in the context of ideological confrontation with Iran, the IS and ABM [7].

A significant moment in the evolution of the political process in the Persian Gulf region was the replacement of the king in the KSA as a result of the death of the head of state Abdallah. The new king Salman differs conservatism and caution in relation to everything new. He does not accept the breaking of traditions and principles. He believes that the state of Al-Saud should develop along the path indicated by its founder, King Abdulaziz. He is a supporter of the preservation of the theocratic absolute monarchy, based on the ideological 
support of the Wahhabi clergy and military cover from the US. He believes that it is inexpedient to liberalize political life in the KSA by Western standards because the development of parliamentary and other democratic institutions in the country, in his opinion, will inevitably lead to the dissociation of the nation by tribal and confessional features. Any opposition political association and their actions are intolerant. In this regard, no softening of the regime in the country is expected, including, with regard to the Shiites of the eastern province of KSA. Moreover, in the face of the growing military and terrorist threat of KSA, King Salman attaches high priority to keeping the security system at a high level. This is evidenced by his personnel decisions in the power bloc. Thus, Prince Mohammed bin Naif, who proved to be an effective Minister of the Interior, still reliably securing the kingdom's security, gained even more authority by assuming the position of a third person in the state hierarchy, the deputy crown prince, which would allow him to make decisions faster and easier through the Government in the interests of strengthening the Ministry of Internal Affairs. The appointment of Prince Mohammed bin Salman, Minister of Defense of KSA, who at the same time became the head of the Royal Chancellery, testifies, according to experts, the desire of the King to maintain personal control over his son over the armed forces, which, if the situation in the Arab region continues to deteriorate and the Iranian military strengthens to be a key guarantor of the security of the As-Saud regime.

Salman's political views suggest that he will continue, although more cautiously than his predecessor, the gradual transformation of the Saudi state towards greater secularization and modernization, since the ruling family has a clear realization that the country cannot exist in isolation.

Analysts believe that in the foreign policy course of Riyadh there will be no fundamental changes. King Salman was a co-thinker of his predecessor Abdallah, together with him participated in the development of the most important decisions and in recent years personally implemented them, being in fact acting head of state. The main priority for King Salman will be the protection and strengthening of the unity of the monarchies of the CCASPG. Within the entire Arab community for the Saudis, after strengthening their front lines (CCASPG, Jordan, Egypt, Yemen, Iran), the first task is to limit the spread of the influence of the Islamic Republic of Iran, the IS, as well as the ideology, the Brotherhood Muslim Association.

In the coming months, priority will be given to Yemen, where the Iranians through the hushes created a threat of destabilization of the southern regions of the KSA, not to mention the interests of the Saudis in Yemen itself.

Through the prism of rivalry with the Iranians, Riyadh will defend the policy towards Islamic countries outside the Arab region (Turkey, Afghanistan, Pakistan, Muslim countries of the CIS).

According to the Saudis, the main problem preventing them from holding back Iran in the region is the steps taken by the Obama administration to get closer to Tehran, the desired result of which declars the removal of the economic sanctions from the IRI in exchange for ensuring transparency and control of the INP. However, this does not mean abandoning the Saudis from a strategic partnership with Washington. In Riyadh, the Americans are still viewed as the only force capable of providing military security to the KSA and the CCASPG in the event of an external military attack. Nevertheless, the Saudis, well aware of the nature of the American government, are trying to use their lobbying capabilities in Washington (primarily among Republicans) to contain the Obama administration's policy of deploying towards cooperation with Tehran, which, in their view, leads to an even stronger political Iran's economic positions in the region to the detriment of the interests of the KSA. To exert pressure on Obama, the Saudis are ready to demonstrate the seriousness of their intentions to diversify their foreign economic and foreign policy ties in favor of alternative partners (the Russian Federation, the PRC, the EU). However, it happens also on the basis of their compliance with the sovereign interests of the KSA (primarily on the Iran issue and related regional problems) and not implying a full reorientation to any of them.

For Riyadh, Moscow, first of all, is an alternative to Washington geopolitical pole, the position of which must be taken into account when building its foreign policy. To date, the KSA has formed the perception of Russia as an independent partner, in relation to which there is a set of both common interests and disagreements in approaches to various problems.

The main political claims of the Saudis against Russia are related to Moscow's regional preferences in favor of Iran. In support of their position, the Saudis lead the frequency of contacts at a high state level, assisting Tehran in implementing the INP, supporting pro-Iranian regimes in Damascus, as well as Lebanese Hezbollah. In this connection, Riyadh closely follows Moscow's approaches to the most important problems of the region for Saudi Arabia (SAR, Iran, Yemen, ARI, Egypt) and weighs the possibility and expediency of rapprochement with Russia based on its sovereign interests.

To date Saud formed a list of bilateral and multilateral issues, on which they are not only willing but also very interested to cooperate with Russia. They are the use of the Russian-Egyptian military-technical cooperation to strengthen the regime of Sisi, the fight against international terrorism and organized crime including drug trafficking, the creation of the nuclear power industry in the KSA, the exchange of assessments about the situation in the world oil and gas market and the search for possible ways to stimulate the growth of prices for hydrocarbons (except for this possibility of rejection of part of its share in the market). The Saudis are ready to build a dialogue on these topics at both the highest and the expert levels.

\section{SUMMARY}

Taking into account the Russian experience in the field of combating terrorism with border protection, with the fight against natural disasters, the $\mathrm{KSA}$ is ready to consider the proposals of the Russian side in the sphere of militarytechnical cooperation. However, at this stage, it is a question of possible experimental purchases of weapons and military equipment and special equipment with the interests of 
individual combat and auxiliary units of the Armed Forces, the Ministry of Internal Affairs, the National Guard, and the GRA. The large-scale military-technical cooperation on equipping and training the army of Saudi Arabia remains for the United States.

Riyadh is clearly aware that Washington would like the KSA to join the sanctions pressure on Moscow and support the West's efforts in Ukraine. This factor for the leadership of the $\mathrm{KSA}$ is an occasion to draw the attention of the Americans to the fact that such a deal would not look logical against the backdrop of Washington's actions leading to the strengthening of Iran, the main opponent of the Saudi regime. This approach of the Saudis gives American hawks - Republicans yet another argument against Obama's policy and rapprochement with Iran. Thus, the current neutrality and even relative cooperation of the Saudis in the Russian direction is more likely to result from disagreements between Riyadh and Washington and may be violated in the event of a reverse reversal.

The main foreign policy interests of Russia in the Arabic Gulf zone are determined by the need to increase confidence and mutually beneficial cooperation, to prevent challenges and threats to the national security of the country [8].

Russia's geopolitical interests in building relations with the KSA and other countries of the region are associated with the multi-vector influence of the Gulf states on a number of CIS countries, as well as on the Islamic and Turkic-speaking republics of the Russian Federation. For Russia, a balanced relationship with the Islamic world is important, since up to 20 million Russians are Muslims. Russia is interested in neutralizing Islamic national-radical currents, which aim to alienate the North Caucasus [9].

\section{Acknowledgment}

The article was prepared within the development program of the Flagship Regional University on the basis of Belgorod State Technological University named after V.G. Shoukhov

\section{References}

[1] V.M. Alchinov Political problems of international economic relations: Textbook, Mocsow: East-West, 2009 p. 192.

[2] Amer Maan "Information war in the conditions of political crisis in the Middle East", Moscow: Bulletin of the People Fiendship University of Russia, 2013, № 1 .

[3] A.I. Abalyan Analysis of the main sources of conflict in the Near Eastern region, Mocsow: Political expertis, 2013, № 2, pp. 1-9.

[4] A. Alvanus, "The Role of the European Union in the Middle East Conflict", Moscow: Young Scientist, 2013, № 5 .

[5] A. Alekseev, "Ilamic Republic of Iran and "Arab Spring": some remarks", Moscow: Russia and the Muslim World, 2013, № 10 (256).

[6] A.V. Baranov "Islamic Awakening" and "Arab Spring": Foreign Policy Doctrine of the Islamic Republic of Iran", Moscow: Izvestiya Saratov University, Series: History, International relationships, 2013, № 3, p. 13.

[7] Volodina N.V. "The activity of the Islamic radical organization "Muslim Brotherhood" in the Arab countries and other countries of the world", Moscow: The legal initiative, 2014, № 1 .

[8] V.I. Annenkov, S.N. Baranoc, D.D. Vazhnov, V.B. Laptev, N.A. Sergeev, Russia's security: geopolitical and military-political aspects, Moscow: RUSAVIA, 2006, 432 p.

[9] Annenkov V.I., Laptev V.B., N.A Sergeev, National Security of Russia Belokrinickyi V.Ya. East in international relations and world politics, A course of lectures, Moscow: East. university, 2009. 